\title{
ROLE OF REHABILITATED TANKS IN IMPROVING WATER SECURITY IN GOMUKHI SUB BASIN OF VELLAR BASIN
}

\author{
E Arivoli ${ }^{1}$, N K Ambujam ${ }^{2}$ \\ ${ }^{1}$ PG student, Centre for Water Resources, Anna University, Tamil Nadu, India \\ ${ }^{2}$ Professor \& Director, Centre for Water Resources, Anna University, Tamil Nadu, India
}

\begin{abstract}
Agriculture is the backbone of Indian economy. India has more number of villages and farming is the main occupation in villages. The artificial application of water to the agricultural lands is basically done through tanks, canals, sprinklers and drips. However tank irrigation is considered as one of the ancient irrigation system since the age of South Indian tanks are several centuries old and had started declining progressively. Due to inadequate rainfall, improper maintenance of tank components the tank irrigation system follows a declining trend, almost all the command area under any tank irrigation system depends on the wells located in the fields. This paper focused on how has the tank rehabilitation helps to improve agricultural production under the tank command and how it improves water security. The tank's performance is assessed through some indicators from engineering aspect, agricultural aspect and financial aspect. Based on the selected engineering indicators the service delivery index for head reach, middle, tail end for the tank command has been calculated. The result shows that the service delivery index is high in head reach, moderate in middle and low in tail end. Agricultural production was increased after the tank rehabilitation and it improves water security. The tank rehabilitation has also increased the water level in the adjacent wells, but there is no direct contribution from the tank to tail end farmers due to siltation of field channels. The wells located in the fields sustaining agriculture in the tail end, however the middle and head reach farmers are practicing conjunctive use of tank and well water.
\end{abstract}

Keywords: Tank Rehabilitation, Water Security, Integrated Approach $* * *$

\section{INTRODUCTION}

It is well known fact that tanks are small reservoirs that are generally constructed in villages for multiple purposes such as domestic, irrigation, livelihood, groundwater recharge; these tanks are considered as one of the biggest assets of villages and are common to all villagers. Tank Irrigation system is a cost effective irrigation system since most of the farmers in the state are marginal farmers. Tanks are classified as system tank and non-system tank based on the inflow, PWD tanks and panchayat tanks based on the ayacut area. A tank has its catchment area, feeder channel, embankment, sluice, weir, field channel and ayacut area. Most of the tanks existing in the state of Tamil Nadu are century years old. Due to inadequate rainfall, encroachment on tank bed, poor maintenance of tank components the tank irrigation system keeps on decreasing. The share of tank irrigation in Tamil Nadu declines to $19 \%$ and the share of well irrigation increased to 50\% (Palanisamy et al, 2000). There is an urge to rehabilitate these tanks and bring their condition to an improved state.

By knowing the significance of tanks the state Government is trying to rejuvenate these tanks under various schemes, many international agencies are also funding for tank rejuvenation in south Asia especially in south India. One such project is TN-IAMWARM, Tamil Nadu Irrigated Agriculture Modernization and Water-Bodies Restoration and Management (IAMWARM) is a Multidisciplinary Project funded by the World Bank. It has been implemented by the Government of Tamil Nadu with Water Resources
Department as the nodal agency. The project has covered 63 selected sub basins out of 127 sub basins and covers an ayacut area of 6.17 lakh hectares.

Under TN-IAMWARM programme, lining of supply channels, desilting of field channels, strengthening of tank bunds, repair to sluices, eviction of encroachment are the works carried out.

\section{STUDY AREA}

A non-system tank 'Niraimathi' and a system tank 'Thenkeeranur big tank' in Kallakurichi block of Villupuram district, Tamil Nadu, India is taken up for the study.The corresponding co-ordinates are $11^{\circ} 42^{\prime} 53.21 " \mathrm{~N}$ and $79^{\circ} 00^{\prime} 8.65^{\prime \prime} \mathrm{E}$ (non-system tank), $11^{\circ} 43^{\prime} 40.00^{\prime \prime} \mathrm{N}$ and $78^{\circ} 58^{\prime} 10.00 " \mathrm{E}$ (system tank).Both the tanks are located in the gomukhi sub basin of vellar basin. There are about 39 system tanks and 41 non system tanks are available in the gomukhi sub basin and all the tanks have been rehabilitated under TN-IAMWARM programme. 60 water user's associations are formed under the same programme. The ayacut area under the non-system tank is 59 ha and 68 ha for system tank, in which paddy and sugarcane are the major crops grown in that area. 4 ha of maize have grown under the system tank command.

\section{METHODOLOGY}

The methodology adopts to assess the performance of rehabilitated tanks using selected indicators. The evaluation 
was made in an integrated approach such that the indicators were selected from engineering aspect, agricultural aspect and financial aspect. The indicators are selected from IWMI (International Water Management Institute, Srilanka) research report no.20 and Base line survey report jointly published by PWD (Public Works Department), Tamil Nadu \& Centre for Water Resources, Anna University. From the selected engineering indicators, Service Delivery Index (SDI) was calculated using weighted average method. Thirty farmers (fifteen from each tank) were selected to calculate the SDI. The weights to each parameter were assigned by farmers and accordingly SDI for head, middle, tail was calculated.

Adequacy, Equity, Timeliness, Repair \& Maintenance, Groundwater recharge are the selected engineering indicators. Output per cropped area, Output per unit irrigation supply is the selected agricultural indicators. Gross return on investment made is the selected financial indicator. The obtained results for both the tanks have been compared.

\section{RESULTS AND DISCUSSIONS}

\subsection{Engineering Indicators}

\subsubsection{Number of Days Water Available in the Tank}

Under the tank rehabilitation programme, the tank bunds are strengthened, thus the leakage of water through tank bund is arrested. The desiltation of tank helps to increase its storage. Thus the water availability in the non-system tank is increased by 25 days and in the system tank it has been increased by 30 days. The surplus of thenkeeranur anicut is diverted to thenkeeranur big tank thus the number of days is more in system tank than the non-system tank. However these values are fluctuating by 5 -10days depends on the annual rainfall.

\subsubsection{Adequacy}

Adequacy of the tank is the ratio between number of days water applied by choice from the tank to the actual number of days water required. The results are tabulated in below in the table 1 .

Table - 1 Adequacy of the tanks

\begin{tabular}{|c|c|c|c|c|}
\hline Parameter & Tank & & lequac & \\
\hline \multirow{6}{*}{ Adequacy } & \multirow{3}{*}{$\begin{array}{c}\text { Non-system } \\
\text { tank } \\
\text { (Niraimathi) }\end{array}$} & Head & 0.91 & 0.3 \\
\hline & & Middle & 0.276 & 0 \\
\hline & & Tail & 0 & 0 \\
\hline & \multirow{3}{*}{$\begin{array}{c}\text { System tank } \\
\text { (Thenkeeran } \\
\text { ur big tank) }\end{array}$} & Head & 0.95 & 0.11 \\
\hline & & Middle & 0.3 & 0 \\
\hline & & Tail & 0 & 0 \\
\hline
\end{tabular}

\subsubsection{Equity}

Equity is the ratio of water delivered to the water required. The delivered water in cumec is measured in the field using float method, whereas the required water is the designed discharge. The results are tabulated in below in the table 2 .
Table - 2 Equity of the tanks

\begin{tabular}{|c|c|c|}
\hline Parameter & Tank & Equity \\
\hline Equity & $\begin{array}{c}\text { Non-system } \\
\text { (Niraimathi) }\end{array}$ & 0.44 \\
\cline { 2 - 3 } & $\begin{array}{c}\text { System (Then } \\
\text { keeranur big tank) }\end{array}$ & 0.3 \\
\hline
\end{tabular}

\subsubsection{Timeliness}

Timeliness is a qualitative indicator which denotes the timely supply of water from the tank. Timeliness is good in head reach for both of the tanks, moderate in middle and there is no contribution to tail end farmers.

\subsubsection{Accountability of Irrigation Staffs}

Whenever there is a problem of leakages in bunds, conflict among farmers, the technical staffs are available to resolve it. The WUA meetings are conducted once in three months by PWD officials. Hence the overall accountability is good in the selected tanks.

\subsubsection{Groundwater Recharge}

Under the rehabilitation programme, the tanks are desilted, thus the number of water availability days increased. The wells around the command area get recharged. The tail end farmers can irrigate two seasons with the help of wells. The groundwater recharge is increased after the tank rehabilitation.

\subsubsection{Service Delivery Index (SDI)}

From the selected engineering indicators, SDI is calculated for Head, Middle, and Tail for both the tanks on a 10 point scale. The results are shown in the table 3

SERVICE DELIVERY INDEX (I)

$$
=\frac{1}{n 2} \sum_{j=1}^{n 2} \frac{\sum_{i=1}^{n 1} F i j S i j}{\sum_{i=1}^{n 1} F i j}
$$

Where

I = Service Delivery Index

Fij $=$ Importanceof $i^{\text {th }}$ parameter as perceived by $\mathrm{j}^{\text {th }}$ respondent

$\mathrm{Sij}=$ Current level of performance given by respondents

$\mathrm{N} 1=$ no of parameters

$\mathrm{N} 2=$ no of respondents in a group

Table $-\mathbf{3}$ SDI for the selected tanks

\begin{tabular}{|c|c|c|c|}
\hline \multirow{2}{*}{ Tank } & \multicolumn{3}{|c|}{ SDI } \\
\cline { 2 - 4 } & Head & Middle & Tail \\
\hline $\begin{array}{c}\text { Non - system tank } \\
\text { (Niraimathi) }\end{array}$ & 7 & 5 & $\begin{array}{c}2.85 \\
(5)\end{array}$ \\
\hline $\begin{array}{c}\text { System tank (Then } \\
\text { keeranur) }\end{array}$ & 6.7 & 4.6 & $\begin{array}{c}2.46 \\
(4.6)\end{array}$ \\
\hline
\end{tabular}


The SDI of non-system tank is quite higher than system tank because of better rehabilitation works carried in Non-system tank. The values which are given in parenthesis denotes the conjunctive use of well and tank irrigation.

\subsubsection{Conveyance Efficiency}

Float method is used to assess the conveyance efficiency of the field channels of the selected tanks. A straight stretch of $20 \mathrm{~m}$ of field channel is selected, a wooden $\log$ is allowed to flow over the water flow, the time taken by the float to reach the stretch is noted using stop watch. The velocity of the flow is measured; the discharge is measured with the help of cross section of the channel. The designed discharge of the channel is obtained from the PWD records, the present discharge is measured after made into III trials and the results are given in the table 4

Table - 4 Conveyance efficiency of field channels

\begin{tabular}{|c|c|c|}
\hline \multirow{2}{*}{ Tank } & \multicolumn{2}{|c|}{ Conveyance efficiency } \\
\cline { 2 - 3 } & $\begin{array}{c}\text { Pre } \\
\text { rehabilitation }\end{array}$ & $\begin{array}{c}\text { Post } \\
\text { rehabilitation }\end{array}$ \\
\hline $\begin{array}{c}\text { Non-system tank } \\
\text { (Niraimathi) }\end{array}$ & $30 \%$ & $45 \%$ \\
\hline $\begin{array}{c}\text { System tank } \\
\text { (Then keeranur } \\
\text { big) }\end{array}$ & $30 \%$ & $30 \%$ \\
\hline
\end{tabular}

\subsection{Agricultural Indicators}

\subsubsection{Output Per Cropped Area}

The ratio of production in local or global price to the cropped area is output per cropped area. The yield of paddy is increased by $526 \mathrm{~kg} / \mathrm{ha}$, the net income for paddy is increased by Rs.7500/ha and there is an increase of 7 tonnes/ha for sugarcane under non-system command area after its rehabilitation. The production remains the same in system tank before and after its rehabilitation. The price of sugarcane per tonne in government mills is nearly twice to private mills. Most of the farmers under system command area selling to government mills hence the net income of sugarcane is more in case of system tank. The results are given in the table 5

Table - 5 Yield analysis of the selected tank commands

\begin{tabular}{|c|c|c|c|}
\hline \multirow[t]{2}{*}{ Tank } & \multirow[t]{2}{*}{ Crop } & \multicolumn{2}{|c|}{ Yield } \\
\hline & & $\begin{array}{c}\text { Pre } \\
\text { rehabiltation }\end{array}$ & $\begin{array}{c}\text { Post } \\
\text { rehabilitation }\end{array}$ \\
\hline \multirow{2}{*}{$\begin{array}{l}\text { Non-system } \\
\text { (Niraimathi) }\end{array}$} & Paddy & $6563 \mathrm{~kg} / \mathrm{ha}$ & $7125 \mathrm{~kg} / \mathrm{ha}$ \\
\hline & Sugarcane & 93tonnes/ha & 100tonnes/ha \\
\hline \multirow{2}{*}{$\begin{array}{l}\text { System (Then } \\
\text { keeranur big) }\end{array}$} & Paddy & $6563 \mathrm{~kg} / \mathrm{ha}$ & $6563 \mathrm{~kg} / \mathrm{ha}$ \\
\hline & Sugarcane & 100tonnes/ha & 100tonnes/ha \\
\hline
\end{tabular}

\subsubsection{Output per unit irrigation supply}

Due to the increase in production the output per unit irrigation supply is increased by Rs. 1.5 for paddy for nonsystem tank and it remains the same (Rs. $11.75 / \mathrm{m}^{3}$ ) for system tank. In case of sugarcane most of the farmers under system tank sold their product in government mills also the cropped area of sugarcane in system tank is more when compared to non-system tank, hence the output per unit irrigation supply is (Rs.9/m3) and Rs. $\left(5.5 / \mathrm{m}^{3}\right)$ for system tank. Rs. $4 / \mathrm{m}^{3}$ is the output per unit irrigation supply for maize under system command area.

\subsection{Financial Indicator}

\subsubsection{Gross Return On Investment}

The ratio of gross or net value of the product, to the cost of irrigation structure is the gross return on investment. Due to the increase in production the Gross return is $57.74 \%$ for Non- system tank. There is no increase in production under system command, thus the gross return is NIL in case of system tank.

\section{CONCLUSIONS}

From the indicators, it can be concluded that the rehabilitation is done well in non-system tank than system tank. The yield is increased after its rehabilitation. An efficient field channel to be constructed to deliver water from tank to the tail end farmers, the efficient field channel will reduce water losses and saves it to a significant value. The rehabilitation recharged the wells (groundwater) hence the farmers can go with the second season with good groundwater support. The water security with respect to irrigation is ensured after the tank rehabilitation programme.

\section{REFERENCES}

[1] Anuradha B, Ambujam N.K, Karunakaran K, Rajeswari B (2009) Water and Energy International, 'Impact of Tank Rehabilitation-An Analytical Study of Peri Urban Tank of Tamil Nadu', Water and Energy International, vol66, pp.17-23

[2] Anuradha B and Ambujam N.K (2010) 'Impact of Water Resources Protection on Local Ground Water Market', Journal of Water Resource and Protection, vol.2, pp. 727-730

[3] Anuradha B and Ambujam N.K (2012) 'Impact of Tank Rehabilitation On Improved Efficiency of Storage Structures', International Journal of Engineering Research and Applications, vol.2, pp. 1941-1943

[4] CWR-PWD Baseline Survey Report for selected Irrigation Commands (2000)

[5] Palanisamy K (2002) Sustainable Management on Tank Irrigation System In India. Bulletin 24, Water Technology Centre, Tamil Nadu Agricultural University Press, Coimbatore

[6] PalanisamiKuppannan, JagadeesanMuniandi, Fujita Koichi, KonoYasuyuki (2008) 'Impacts of the Tank Modernization Programme on Tank Performance in Tamil Nadu state, India'

[7] Priyadharshani R (2013) 'A study on Irrigation service delivery of canal and tank Irrigation system in Tamil Nadu', M.E Thesis, Centre for Water Resources, Anna University, Chennai 
[8] Sakthivadivel R, Christopher J. Perry, Charlotte de Fraiture and Wim H. Kloezen (1998), Report No.20 Indicators for comparing performance of irrigated agricultural system, International Water Management Institute, Sri Lanka

[9] 'Vellar Basin Report', Institute of Water Studies(2013), Vol I\&II,Tharamani, Chennai Tamil Nadu

[10] Shanmugam C R and Kanagavalli J, 'Technology of Tanks', reflection publications trust, revised edition, 20

\section{BIOGRAPHIES}

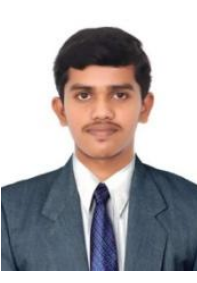

Final year post graduate student of Integrated Water Resources Management, Centre for Water Resources, Anna University, Chennai. This project has been funded by IDRC-canada and Saci Waters, Hyderabad, India.

E-mail : arivoli.e@gmail.com

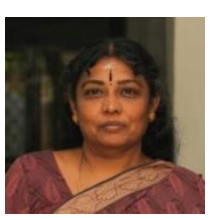

Professor and Director, Centre for Water Resources, Anna University, Chennai. She is specialized in evaluating performance of tank irrigation systems, waste water irrigation and optimization techniques. She has guided several Ph.D's and M.E thesis. 